\title{
MÉRNÖKHALLGATÓK KOMPETENCIAFELMÉRÉSE A DE MÚSZAKI KARON
}

\section{THE ENGINEERING STUDENT COMPETENCY ASSESSMENTS OF THE UNIVERSITY OF DEBRECEN FACULTY OF ENGINEERING}

\author{
Szabó Fruzsina ${ }^{1}$, Kovács Sándor ${ }^{2}$, Szücs Edit $^{3}$ \\ ${ }^{1}$ Debreceni Egyetem Müszaki Kar Müszaki Menedzser és Vállalkozási Tanszék; \\ 4028 Magyarország, Debrecen, Ótemető utca 2-4; Telefon: +3630/9200281 \\ szabofruzsi77@gmail.com \\ 2 Debreceni Egyetem Gazdaságtudományi Kar Kutatásmódszertan és Statisztika \\ Tanszék; 4032 Magyarország, Debrecen, Böszörményi út 132; \\ kovacs.sandor@econ.unideb.hu \\ ${ }^{3}$ Debreceni Egyetem Müszaki Kar Müszaki Menedzser és Vállalkozási Tanszék; \\ 4028 Magyarország, Debrecen, Ótemetö utca 2-4; edit@eng.unideb.hu
}

\begin{abstract}
The examination was made on Engineering students of the University of Debrecen. Our research was based upon the Graduate Career Monitoring System serving the competence assessment analyzing the data among them. Students and absolwent and the labor participants were analyzed during our research. SPSS software, Chi 2 analysis and Median test applications were used during the test. Conclusions were drawn based on these; and also we made proposals on improving the system.
\end{abstract}

Keywords: DPR (Graduate Career Monitoring System), student, labor market, competency.

\section{Összefoglalás}

Munkánk során a Debreceni Egyetem mérnökszakos hallgatóinak kompetenciáját vizsgáltuk. A kutatás háttereként a Diplomás Pályakövető Rendszer szolgált, melynek a kompetenciamérés adatait elemeztük a mérnökhallgatók körében. A kutatás során az aktív hallgatók a végzett hallgatók és a munkaerő piaci résztvevők véleményét vizsgáltuk a témában. Az SPSS szoftver, a Chí2 elemzés és Medián próba alkalmazásával következtetéseket vontunk le és ezek alapján javaslatokat tettünk a rendszer javítására.

Kulcsszavak: DPR (Diplomás Pályakövető Rendszer), hallgató, munkaerö piac, kompetencia.

\section{Bevezetés}

Az elmúlt években a felsőoktatás számtalan változáson esett át, ezért az egyetemek között kompetitív helyzet alakult ki. Ezt az utóbbi idő demográfia mélypontja, a szüle- tések számának visszaesése, ezáltal a hallgatói létszám csökkenése idézte elö. A bolognai rendszer bevezetése szintén komoly feladat volt az oktatási rendszer résztvevőinek. Az egyetemi képzések során fokozott figyelmet kell fordítani arra, hogy a meg- 
szerzett tudás hasznos legyen a diplomások számára.

Számos országban végeznek kutatásokat a végzett diákok és a munkaerő piaci szereplök körében, hogy a kapott válaszokat felhasználva, javítani tudjanak az oktatási színvonalon. A kompetenciaméréssel hozzájárulhatunk az oktatás- szerkezetének és tudományos tartalmainak- fejlesztéséhez, az egyetemek által felkínált szolgáltatások tárházának és színvonalának növeléséhez. Maga a mérés segít nekünk abban, hogy pontosabb képet kapjunk a munkával kapcsolatos attitüdökröl, az ismeretek és készségek fejlesztéséről [1]

A legfontosabb feladat, hogy a végzett hallgatók a munkaerő piacon minél hamarabb, a számukra megfelelö munkakörbe tudjanak elhelyezkedni. Ennek eléréséhez szükséges, hogy olyan mindenki számára fontos kompetenciákkal rendelkezzenek, melyek megfelelnek az igényeknek.

A középiskolából kilépő diákoknak nehéz eldönteniük, hogy mit szeretnének csinálni, melyik az a felsőoktatási intézmény, amit válasszanak, és amelynek elvégzése olyan kompetenciákat ad számukra, amelylyel meg tudják állni helyüket a munka világában.

Ezért az egyetemeknek egy olyan rendszert kell használniuk, ami elősegíti őket abban, hogy információt tudjanak gyüjteni a végzett hallgatóktól arról, hogy a gyakorlatuk minősége és hossza kielégítő volt e. Az információk gyüjtéséhez a pályakövető rendszer nyújt segítséget, amelyben nem csak a végzett hallgatókat és a munkaerő piaci részvevőket vizsgálják, de az aktív hallgatókat is, hogy milyen készségeket és képességeket tartanak fontosnak a későbbi elhelyezkedés szempontjából. Ezen képességeket a mérés után azonosítani tudjuk és a későbbiekben fejleszteni a körükben különböző tréningek segítségével. [2]

\section{Anyag és módszer}

Munkánk célja, hogy a kompetenciamérés eredményeit úgy elemezzük, hogy azok reprezentatív és hasznos információkat biztosítsanak. Ezáltal teszünk javaslatot a rendszer fejlesztésére.

Munkánk felépítése során bemutatjuk a kompetencia fogalmát, annak lényegi elemeit és fontosságát. Mindezek alatt sorba vesszük, miként hasznosíthatjuk a munkaerő piacon való elhelyezkedésnél ezek fejlesztését.

Majd leírjuk a Diplomás Pályakövető Rendszer lényegét, felépítését és müködési elvét. Sorra vesszük az SPSS szoftvert, a Chi ${ }^{2}$ elemzés és a Medián próba statisztikai módszereket.

Kutatásunk vizsgálati alanyául a mérnökképzést választottuk, mivel magam is mérnökhallgató vagyok a Debreceni Egyetemen. Így a Debreceni Egyetem Müszaki Karán végeztük el a vizsgálatokat. Ennek folytán kitértünk a mérnöki életpálya fontosságára, hivatásának jelentőségére és a mérnöki szemléletre.

Elemzéseinkhez a Debreceni Egyetem Diplomás Pályakövető Rendszerének kérdőívét és eredményeit alkalmaztuk. A kutatás három csoport köré épült. Ezek a következők: az aktív és a végzett hallgatók, valamint a munkaerő piaci szereplők.

Vizsgáltuk a munkával kapcsolatos attitüdök fontosságát, valamint az ismeretek, készségek fejlesztéséről alkotott véleményeket.

A vizsgálat több szempontból is reprezentatívnak mondható, mivel nemre, képzési szintre és szakra is kitért és a válaszadók száma is megfelelően magas volt.

A nemek arányában a válaszadások egyharmad-kétharmad (26,5\% nő és $73,5 \%$ féri) arányban oszlanak meg a nők és a férfiak között. Az alap- és mesterképzés aránya 95-5\%. A szakokat összehasonlítva a gépészmérnök hallgatók válaszadási kedve volt a legjelentősebb. 
Első körben a három vizsgálati csoport szemszögéből tértünk ki a munkával kapcsolatos attitüdök fontosságára, valamint az ismeretek, készségek fejlesztéséröl alkotott véleményükre. A munkával kapcsolatos attitüdöknél elmondható, hogy válaszadóink közel azonosan ítélték meg ezek fontosságát, összességében nem figyelhető meg nagyobb eltérés egyik csoport esetében sem. Vannak olyan kompetenciák, melyeket mind három csoport egyaránt háttérbe szorított, véleményük szerint kevésbé fontosak. Ezzel szemben az ismeretek és készségek fejlesztésénél már másképp gondolkodtak (1. ábra). A munkaerő piac számára minden egyes kompetencia magasabb értéket ért el a másik két csoporthoz képest.

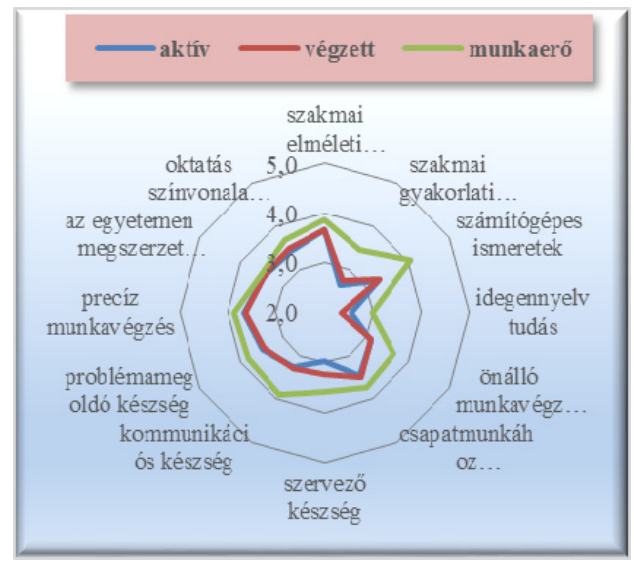

1. ábra. Válaszadói csoportok véleménye az ismeretek készségek fejlesztéséröl

Meglepően tapasztalhatjuk, hogy az idegen nyelvi ismeretek és a szakmai gyakorlatban való jártasság kompetenciái alacsonyabb pontátlagot érteket el a többihez képest.

A következőkben már csak az aktív és végzett hallgatói csoportok véleményét vizsgáltuk különböző aspektusokban.

Szakonként pókháló-diagramon ábrázoltuk a két csoport munkával kapcsolatos attitüdjeit. Meg kell említenünk azt is, hogy az aktív és végzett hallgatók válaszadásai- nak párhuzamba állításánál csupán négy szak esetén vonhatunk le összehasonlító következtetéseket, mivel a kérdöívet kitöltők között csak négy szak végzettjei szerepelnek. Az aktív hallgatók esetében a különböző szakok válaszadásai között szignifikáns eltérés a „figyelmet szentel a részleteknek a feladat elvégzése során” és a „motiválja őket a nehéz feladatok elvégése" attitüdök esetén volt. Ezzel szemben a végzett hallgatóknál szignifikáns eltérés nem mutatott ki a statisztikai vizsgálat, viszont az építészmérnökök egy-két kompetenciát többre értékeltek. Az aktív és végzett hallgatók visszajelzéseiböl kiderül, hogy kevésbé fontos jellemvonásnak tekintik az irányítás magukhoz ragadását.

$\mathrm{Az}$ ismeretek és készségek szakonkénti ábrázolásánál jelentős különbségek vannak a válaszadások között. Az aktív hallgatók esetében ezek a különbségek a szakmai gyakorlatra, az idegen nyelv tudására, az oktatás színvonalára vonatkoznak. Ezzel szemben a végzetteknél a szakmai elméleti alapok, a szakmai gyakorlati jártasság és a problémamegoldó készség területén vélünk felfedezni különbségeket. A különböző szakok aktív és végzett státusztól függetlenül eltérően értékelik a szakmai gyakorlatban való jártasság jelentőségét.

$\mathrm{Az}$ értékelések során a szakonkénti vizsgálatokban BSc szakos hallgatók körében adott válaszokat vettük alapul, ezt később kiegészítettük az MSc szakos hallgatók válaszadásaival, $\mathrm{s}$ e két képzési szintet vizsgáltuk az aktív és végzett hallgatói csoportok körében. A munkával kapcsolatos attitüdjeik tekintetében mindkét csoport esetében háttérbe szorul az irányításra való hajlamuk. Továbbá megfigyelhető, hogy az MSc szakos hallgatók véleménye nagyjából hozzáidomul a korábban vizsgált válaszokhoz.

$\mathrm{Az}$ ismeretek és készségek esetében is megállapítható, hogy a csoportok ezen felbontásában és bővítésében is a szakmai 
gyakorlati jártasság és az idegen nyelvtudás fontossága háttérbe szorul.

\section{3. Összefoglalva}

Összességében megállapítható, hogy a 13 attitüdöt és a 12 ismeretet/készséget minden vizsgálat esetén a válaszadók közel azonos pontátlaggal értékelték. Tehát az 1-2 kiugró elemtől eltekintve a különböző kompetenciák egyformán fontosak a hallgatók számára. Továbbá elmondható, hogy mindez összhangban áll a munkaerő piac szereplőinek véleményével is.

\section{Javaslattétel}

Fejlesztési javaslatunk a következő ezen a területen. Az első éves hallgatókat kell tanulmányunk célpontjába állítani. A változtatásra azért van szükség, mert első évtől van még a legtöbb lehetőség a hiányos kompetenciák elsajátítására, a meglévők fejlesztésére. Emellett a munkaerő piacon résztvevő cégek és vállalatok számát is növelni kell a felmérés során, valamint a végzett hallgatókat is jobban kell ösztönözni a válaszadásra. Miután a végzett hallgatók és a munkaerő piac véleményét meghatározzuk a kiértékelés alkalmával, az első éves hallgatók véleményével is össze kell vetni. Az eltérésekre, azaz a hiányos készségekre és képességekre különbözö kompetencia fejlesztő tréningeket kell szervezni a karon. Miután a fejlesztések, tréningek megtörténtek a hallgatók körében, a végzős évükben egy visszamérést alkalmazhatunk. A célunk az, hogy a visszamérés alkalmával olyan eredményeket kapjunk, melyek közelítenek a munkaerő piaci elvárásokhoz. Tehát lényegében egy olyan komplex rendszer kialakítása a cél, melyben a munkaerő piaci résztvevők elvárásai, valamint a visszamérés alkalmával a hallgatók véleménye közel hasonló értékeket mutat. Ennek eléréséhez pedig az egyetemi évek alatt nyújtott újabb úgynevezett szolgáltatások, különböző tréningek, kurzusok nyújtanának segítséget.

\section{Szakirodalmi hivatkozások}

[1] Fónai M., Szücs E. (szerk.) (2012): A Debreceni Egyetem „Diplomás Pályakövetö Rendszerének" föbb eredményei és tapasztalatai 2010 - 2011, Debrecen

[2] Ádámku R. (2013): A Debreceni Egyetem Gazdálkodástudományi és Vidékfejlesztési karának Emberi erőforrás tanácsadó $M A$ szakon végzett hallgatók pályakövetéses vizsgálata, Debrecen 